\title{
Determinan Kelengkapan Imunisasi Lanjutan pada Balita di Wilayah Kerja Puskesmas Leupung Kabupaten Aceh Besar
}

\section{Determinants of Completeness of Advanced Immunization for Toddlers in Work Area Leupung Health Center of Aceh Besar District}

\author{
Faradilla Safitri*1, Fauziah Andika ${ }^{2}$, Cut Asiah ${ }^{3}$ \\ Universitas Ubudiyah Indonesia, Jln. Alue Naga Desa Tibang, Kecamatan Syiah Kuala, Banda Aceh, Indonesia \\ *Correspoding Author : faradilla@uui.ac.id
}

\begin{abstract}
Abstrak
Imunisasi lanjutan merupakan ulangan imunisasi dasar untuk mempertahankan tingkat kekebalan dan untuk memperpanjang masa perlindungan optimal dari pemberian imunisasi lanjutan dan ini hanya didapatkan apabila anak tersebut telah mendapatkan imunisasi dasar secara lengkap. Cakupan balita yang mendapatkan imunisasi lanjutan (DPT-HB-Hib dan campak) pada tahun 2019 adalah $75,95 \%$, namun $50 \%$ provinsi masih belum dapat mencapai target, salah satunya Provinsi Aceh $(26,91 \%)$. Tujuan penelitian ini adalah untuk mengetahui hubungan pengetahuan, sikap, dukungan suami dan dukungan peran petugas kesehatan dengan kelengkapan imunisasi lanjutan pada balita diwilayah kerja Puskesmas Leupung Aceh Besar. Penelitian ini bersifat analitik dengan pendekatan crossectional, populasi dalam penelitian ini adalah semua ibu yang memiliki balita usia 3-5 tahun sebanyak 132 orang, sampel diambil secara simple random sampling sebanyak 57 orang. Pengumpulan data penelitian telah dilakukan dari tanggal 9 Juni - 17 Juni 2020, instrument penelitian menggunakan kuesioner, pengolahan data menggunakan computer dan analisis data secara univariate dan bivariate. Hasil penelitian analisis bivariate didapatkan pada variabel pengetahuan ( $p$ value $=0.0001$, $\mathrm{OR}=29.333$ ), sikap ( $p$ value $=0.0001, \mathrm{OR}=40.250)$, dukungan suami ( $p$ value $=0.0001$, $\mathrm{OR}=70.000)$, dukungan petugas kesehatan $(p$ value $=0.045, \mathrm{OR}=5.804)$. Kesimpulan dalam penelitian ini adalah ada hubungan pengetahuan, sikap, dukungan suami dan dukungan keluarga dengan kelengkapan imunisasi lanjutan pada balita di wilayah kerja Puskesmas Leupung Kabupaten Aceh Besar. Diharakan kepada petugas kesehatan agar dapat memberikan edukasi kepada ibu, suami dan keluarganya tentang pentingnya pemberian imunisasi lanjutan pada balita guna untuk mengurangi angka kesakitan, kecacatan dan kematian yang disebabkan oleh penyakit yang dapat dicegah dengan imunisasi.
\end{abstract}

Kata Kunci : Imunisasi lanjutan, pengetahuan, sikap, dukungan suami, dukungan petugas kesehatan

\begin{abstract}
Advanced immunization is a repeat of basic immunization to maintain the level of immunity and to extend the optimal protection period from further immunization and this is only obtained if the child has received complete basic immunization. The coverage of children under five who received advanced immunization (DPT-HB-Hib and measles) in 2019 is $75.95 \%$, however $50 \%$ of the provinces have not yet achieved the target, one of which is Aceh Province $(26.91 \%)$. The purpose of this study was to determine the relationship between knowledge, attitudes, support from husbands and support for the role of health workers with the completeness of advanced immunization for children under five in the working area of the
\end{abstract}


Journal of Healthcare Technology and Medicine Vol. 6 No. 2 Oktober 2020

Universitas Ubudiyah Indonesia

e-ISSN : 2615-109X

Leupung Aceh Besar Community Health Center. This research is analytic with a crosssectional approach, the population in this study were all mothers who have children aged 3-5 years as many as 132 people, the sample was taken by simple random sampling of 57 people. The research data collection was carried out from 9 June - 17 June 2020, the research instrument used a questionnaire, data processing using computers and data analysis were univariate and bivariate. The results of the research on bivariate analysis were found in the variable knowledge $(\mathrm{p}$ value $=0.0001, \mathrm{OR}=29.333)$, attitude $(\mathrm{p}$ value $=0.0001, \mathrm{OR}=40.250)$, husband's support ( $\mathrm{p}$ value $=0.0001, \mathrm{OR}=70.000$ ), support from health workers ( $\mathrm{p}$ value $=$ 0.045 , OR $=5.804$ ). The conclusion in this study is that there is a relationship between knowledge, attitudes, husband's support and family support with the completeness of advanced immunization for children under five in the working area of Puskesmas Leupung, Aceh Besar District. It is advisable for health workers to be able to provide education to mothers, husbands and their families about the importance of providing advanced immunization to children under five in order to reduce morbidity, disability and death caused by diseases that can be prevented by immunization.

Keywords: Advanced immunization, knowledge, attitudes, support from husbands, support from healt works

\section{PENDAHULUAN}

Imunisasi adalah suatu upaya untuk menimbulkan dan meningkatkan kekebalan seseorang secara aktif terhadap suatu penyakit sehingga bila suatu saat terpajan dengan penyakit tersebut tidak akan sakit atau hanya mengalami sakit ringan, dengan tujuan utama untuk memberikan perlindungan terhadap penyakit yang dapat dicegah dengan imunisasi, menurunkan angka kesakitan, kecacatan dan kematian akibat penyakit yang dapat dicegah dengan imunisasi ${ }^{1}$.

Ketika anak diusia Batita, mulai diberikan imunisasi lanjutan atau imunisasi ulangan (booster). Imunisasi tahap kedua ini sesuai dengan kebijakan Kementrian Kesehatan yang dalam kajiannya menyimpulkan bahwa imunisasi DPT-HB Hib diberikan dalam 2 tahap, yaitu tahap pertama sebanyak 3 kali (imunisasi dasar), dan dilanjutkan tahap kedua pada usia 18 bulan yang berguna untuk mempertahankan dan meningkatkan titer antibody pada anak yang menurun pada kasus penyakit DPT diusia 15-18 bulan ${ }^{2}$.

Imunisasi lanjutan merupakan ulangan imunisasi dasar untuk mempertahankan tingkat kekebalan dan untuk memperpanjang masa perlindungan anak yang sudah mendapatkan imunisasi dasar yaitu dengan diberikan 1 dosis DPT-HB-Hib pada usia 18 bulan dan 1 dosis campak/MR pada usia 24 bulan. Perlindungan optimal dari pemberian imunisasi lanjutan ini hanya didapatkan apabila anak tersebut telah mendapatkan imunisasi dasar secara lengkap ${ }^{3}$. 
Journal of Healthcare Technology and Medicine Vol. 6 No. 2 Oktober 2020

Universitas Ubudiyah Indonesia

e-ISSN : 2615-109X

Imunisasi lanjutan pada balita (dibawah tiga tahun) yaitu DPT-HB Hib dan Campak. Imunisasi lanjutan/booster perlu diberikan karena berfungsi untuk mempertahankan kadar kekebalan dan memperpanjang masa perlindungan. Imunisasi lanjutan DPT-HB-HIB saat anak berusia 18 bulan atau 1,5 tahun kekebalan yang terbentuk setelah pemberian DPT-HB-Hib 3 dosis sebelumnya akan menurun pada saat anak mencapai usia 15 bulan sampai dengan 1,5 tahun, serta meningkatnya KLB campak di Indonesia, maka imunisasi lanjutan (booster) perlu diberikan ${ }^{4}$.

Sekitar 1,5 juta anak di dunia mengalami kematian tiap tahunnya karena penyakit yang dapat dicegah dengan imunisasi. Pada 2018, terdapat kurang lebih 20 juta anak tidak mendapatkan imunisasi lengkap dan bahkan ada anak yang tidak mendapatkan imunisasi sama sekali. Dan pada tahun 2019 jumlah ini meningkat menjadi 25,7 juta anak yang tidak mendapatkan imunisasi lengkap ${ }^{5}$.

Campak merupakan salah satu penyakit yang dapat dicegah dengan imunisasi. Suspek campak pada tahun 2019 tersebar hampir di seluruh wilayah Indonesia, dengan Incidence Rate (IR) sebesar 3,29 per 100.000 penduduk. Angka tersebut meningkat jika dibandingkan tahun 2018 yang sebesar 3,18 per 100.000 penduduk. Walaupun jumlah kasus suspek campak meningkat pada tahun $2019^{6}$.

Difteri juga merupakan salah satu penyakit yang dapat dicegah dengan pemberian imunisasi. Kasus difteri pada tahun 2019 menyebar hampir di semua wilayah Aceh. Jumlah kasus difteri tahun 2019 sebanyak 130 kasus, jumlah kematian sebanyak 7 kasus, dengan CFR sebesar 5\%. Jumlah kasus ini menurun dibandingkan tahun 2018 (200 kasus). Namun, jumlah kematian akibat difteri meningkat dari tahun sebelumnya (3 kasus). Begitu pula dengan penyebaran kasus suspek campak terdapat hampir di seluruh wilayah Aceh. Terdapat 2,986 kasus suspek campak, jauh lebih tinggi dibandingkan tahun 2018 yaitu sebesar 2,142 kasus. Suspek campak terbanyak terdapat di Kabupaten Pidie (470 kasus), di ikuti Aceh Besar (414 kasus), Bireuen (370 kasus), dan Kota Banda Aceh (327 kasus) ${ }^{7}$.

Cakupan balita yang mendapatkan imunisasi lanjutan/ booster (DPT-HB-Hib dan campak) pada tahun 2019 adalah 75,95\%. Angka ini telah memenuhi target Renstra tahun 2019 yaitu $70 \%$. Namun 50\% provinsi masih belum dapat mencapai target. Provinsi dengan cakupan terendah adalah Aceh (26,91\%), Papua (41,95\%) dan Nusa Tenggara Timur $(43,2 \%)^{6}$.

Puskesmas Leupung merupakan salah satu puskesmas yang berada di Kabupaten Aceh Besar, Wilayah kerja Puskesmas Leupung Kecamatan Leupung terdiri dari 6gampong(Deah Mamplam, Lamseunia, Layeun, Meunasah Bak Ue, Meunasah Mesjid dan Pulot) dimana 
Journal of Healthcare Technology and Medicine Vol. 6 No. 2 Oktober 2020

Universitas Ubudiyah Indonesia

e-ISSN : 2615-109X

berdasarkan data terakhir yang diperoleh masih ada desa atau gampong belum merupakan desa/kelurahan UCI, artinya pemberian imunisasi masih belum merata dan mencakup semua desa karena masih terdapat gampong dimana jumlah bayi yang mendapat imunisasi dasar lengkap kurang dari $80 \%$.

\section{METODE PENELITIAN}

Penelitian ini menggunakan jenis penelitian yang bersifat analitik dengan desain crosssectional. Populasi dalam penelitian ini adalah seluruh ibu yang memiliki balita usia 3-4 tahun dan berada di wilayah kerja Puskesmas Leupung Kabupaten Aceh Besar yaitu sebanyak 132 orang, sampel diambil secara simple random sampling yaitu sebanyak 57 orang. Instrumen penelitian ini menggunakan kuesioner yang telah dilakukan uji validitas dan reliabilitas dan pengumpulan data dengan cara membagikan kuesioner. Pengumpulan data telah dilaksanakan pada 9 Juni sampai dengan 17 Juni 2020 di Wilayah Kerja Puskesmas Leupung Kabupaten Aceh Besar. Pengolahan data menggunakan komputer melalui proses editing, coding, transferring dan tabulating. Analisis data dengan dua data yaitu analisis univariat dan bivariat.

\section{HASIL PENELITIAN}

Tabel. 1

Distribusi frekuensi kelengkapan imunisasi lanjutan, umur ibu, jenis kelamin anak, pendidikan, pekerjaan, pengetahuan, sikap, dukungan suami dan dukungan petugas kesehatan di wilayah kerja Puskesmas Leupung Kabupaten Aceh Besar

\begin{tabular}{clcc}
\hline No & \multicolumn{1}{c}{ Variabel } & Frekuensi (f) & Persentase (\%) \\
\hline 1. & Imunisasi Lanjutan & & \\
& a. Lengkap & 24 & 42.1 \\
& b. Tidak Lengkap & 33 & 57.9
\end{tabular}

2. Umur Ibu
a. 20-29 tahun
18
31.6
b. 30-39 tahun
30
52.6
c. 40-49 tahun
9
15.8

3. Jenis Kelamin Anak
a. Laki-laki
b. Perempuan

4. Pendidikan Ibu
a. Tinggi
b. Rendah 
Journal of Healthcare Technology and Medicine Vol. 6 No. 2 Oktober 2020

Universitas Ubudiyah Indonesia

e-ISSN : 2615-109X

5. Pekerjaan Ibu
a. Tidak Bekerja
49
86.0
b. Bekerja
8
14.0

6. Pengetahuan
a. Tinggi
31
54.4
b. Rendah
26
45.6

7. Sikap
a. Positif
35
61.4
b. Negatif

8. Dukungan Suami
a. Mendukung
24
42.1
b. Tidak Mendukung

9. Dukungan Petugas Kesehatan
a. Mendukung
b. Tidak Mendukung

\section{Total}

57

100.0

Berdasarkan tabel. 1 dapat dilihat bahwa dari 57 responden, balita yang tidak mendapatkan imunisasi lanjutan lengkap sebanyak 33 orang (59.9\%), umur ibu dalam rentang 30-39 tahun sebanyak 30 orang (52.6\%), balita yang berjenis kelamin perempuan sebanyak 33 orang $(57.9 \%)$, pendidikan ibu yang rendah sebanyak 48 orang $(84.2 \%)$, ibu yang tidak bekerja sebanyak 49 orang $(86.0 \%)$, ibu yang berpengetahuan tinggi sebanyak 31 orang (54.4\%), ibu yang memiliki sikap positif sebanyak 35 orang (61.4\%), ibu yang tidak mendapatkan dukungan suami sebanyak 33 orang $(57.9 \%)$, dan ibu yang mendapatkan dukungan dari petugas kesehatan yaitu sebanyak 50 orang $(87.7 \%)$.

Tabel 2

Hubungan Pengetahuan dengan Kelengkapan Imunisasi Lanjutan pada Balita di Wilayah Kerja Puskesmas Leupung Kabupaten Aceh Besar

\begin{tabular}{|c|c|c|c|c|c|c|c|c|c|}
\hline \multirow[t]{3}{*}{ No } & \multirow[t]{3}{*}{ Pengetahuan } & \multicolumn{4}{|c|}{ Imunisasi Lanjutan } & \multirow{2}{*}{\multicolumn{2}{|c|}{ Jumlah }} & \multirow{3}{*}{$\begin{array}{c}\mathbf{P} \\
\text { Value }\end{array}$} & \multirow[t]{3}{*}{ OR } \\
\hline & & \multicolumn{2}{|c|}{ Lengkap } & \multicolumn{2}{|c|}{ Tidak Lengkap } & & & & \\
\hline & & $\mathbf{f}$ & $\%$ & $\mathbf{f}$ & $\%$ & $\mathbf{n}$ & $\%$ & & \\
\hline 1 & Tinggi & 22 & 71.0 & 9 & 29.0 & 31 & 100.0 & 0.0001 & 29.333 \\
\hline 2 & Rendah & 2 & 7.7 & 24 & 92.3 & 26 & 100.0 & & \\
\hline
\end{tabular}

Berdasarkan tabel.2 dapat dilihat bahwa dari 26 responden yang berpengetahuan rendah dan tidak lengkap memberikan imunisasi lanjutan pada balitanya sebanyak 24 orang (92.3\%), 
Journal of Healthcare Technology and Medicine Vol. 6 No. 2 Oktober 2020

Universitas Ubudiyah Indonesia

e-ISSN : 2615-109X

sedangkan dari 31 responden yang berpengetahuan tinggi dan tidak lengkap memberikan imunisasi lanjutan pada balita sebanyak 9 orang $(29.0 \%)$.

Hasil uji statistik diperoleh $p$-value $=0.0001$, artinya ada hubungan yang signifikan antara pengetahuan ibu dengan kelengkapan imunisasi lanjutan pada balita di wilayah kerja Puskesmas Leupung Kabupaten Aceh Besar, dan nilai OR = 29.333, yang berarti ibu yang berpengetahuan rendah tentang imunisasi lanjutan pada balita memiliki peluang 29 kali lebih besar untuk tidak memberikan imunisasi lanjutan secara lengkap kepada balitanya dibandingkan dengan ibu dengan pengetahuan tinggi terhadap pemberian imunisasi lanjutan.

Tabel 3

Hubungan Sikap dengan Kelengkapan Imunisasi Lanjutan pada Balita di Wilayah Kerja Puskesmas Leupung Kabupaten Aceh Besar

\begin{tabular}{cccccccccc}
\hline No & Sikap & \multicolumn{4}{c}{ Imunisasi Lanjutan } & \multicolumn{2}{c}{ Jumlah } & \multicolumn{1}{c}{ P } & OR \\
& & \multicolumn{2}{c}{ Lengkap } & \multicolumn{2}{c}{ Tidak Lengkap } & & & Value & \\
& & f & \% & f & \% & n & \% & & \\
\hline 1 & Positif & 23 & 65.7 & 12 & 34.3 & 35 & 100.0 & 0.0001 & 40.250 \\
2 & Negatif & 1 & 4.5 & 21 & 95.5 & 22 & 100.0 & & \\
\hline
\end{tabular}

Berdasarkan tabel 3, dapat dilihat bahwa dari 22 responden, ibu yang memiliki sikap negatif sebanyak 21 orang (95.5\%) tidak memberikan imunisasi lanjutan secara lengkap untuk balitanya, sedangkan dari 35 responden, ibu yang memiliki sikap positif sebanyak 12 orang (34.4) juga tidak memberikan imunisasi lanjutan lengkap pada balitanya.

Hasil uji statistik diperoleh $p$-value $=0.0001$, artinya ada hubungan yang signifikan antara sikap ibu dengan kelengkapan imunisasi lanjutan pada balita di wilayah kerja Puskesmas Leupung Kabupaten Aceh Besar, dan nilai OR = 40.250, yang berarti ibu yang memiliki sikap negative terhadap imunisasi lanjutan memiliki peluang 40 kali lebih besar untuk tidak memberikan imunisasi lanjutan secara lengkap pada balitanya dibandingkan dengan ibu yang memiliki sikap positif terhadap pemberian imunisasi lanjutan.

Tabel 4

Hubungan Dukungan Suami dengan Kelengkapan Imunisasi Lanjutan pada Balita di Wilayah Kerja Puskesmas Leupung Kabupaten Aceh Besar

\begin{tabular}{|c|c|c|c|c|c|c|c|c|c|}
\hline \multirow[t]{3}{*}{ No } & \multirow{3}{*}{$\begin{array}{c}\text { Dukungan } \\
\text { Suami }\end{array}$} & \multicolumn{4}{|c|}{ Imunisasi Lanjutan } & \multirow{2}{*}{\multicolumn{2}{|c|}{ Jumlah }} & \multirow{3}{*}{$\begin{array}{c}\mathbf{P} \\
\text { Value }\end{array}$} & \multirow[t]{3}{*}{ OR } \\
\hline & & \multicolumn{2}{|c|}{ Lengkap } & \multicolumn{2}{|c|}{ Tidak Lengkap } & & & & \\
\hline & & $\mathbf{f}$ & $\%$ & $\mathbf{f}$ & $\%$ & $\mathbf{n}$ & $\%$ & & \\
\hline 1 & Mendukung & 21 & 87.5 & 3 & 12.5 & 24 & 100.0 & 0.0001 & 70.000 \\
\hline
\end{tabular}


Journal of Healthcare Technology and Medicine Vol. 6 No. 2 Oktober 2020

Universitas Ubudiyah Indonesia

e-ISSN : 2615-109X

$\begin{array}{llllllll}2 & \text { Tidak } & 3 & 9.1 & 30 & 90.9 & 33 & 100.0\end{array}$

Mendukung

Berdasarkan tabel 4, dapat dilihat bahwa dari 33 responden, yang tidak mendapatkan dukungan dari suami sebanyak 30 orang (90.9\%) tidak memberikan imunisasi lanjutan lengkap pada balita, sedangkan dari 24 responden, yang mendapatkan dukungan dari suami sebanyak 3 orang $(12.5 \%)$ tidak memberikan imunisasi lanjutan lengkap pada balita.

Hasil uji statistik diperoleh $p$ value $=0.0001$, artinya ada hubungan yang bermakna antara dukungan suami dengan kelengkapan imunisasi lanjutan pada balita di wilayah kerja Puskesmas Leupung Kabupaten Aceh Besar, dan nilai OR $=70.000$, yang berarti ibu yang tidak mendapatkan dukungan dari suami mempunyai peluang 70 kali lebih besar untuk tidak mendapatkan imunisasi lanjutan pada balitanya dibandingkan dengan ibu yang mendapatkan dukungan dari suami.

Tabel 5

Hubungan Dukungan Petugas Kesehatan dengan Kelengkapan Imunisasi Lanjutan pada Balita di Wilayah Kerja Puskesmas Leupung Kabupaten Aceh Besar

\begin{tabular}{llcccccccc}
\hline No & $\begin{array}{c}\text { Dukungan } \\
\text { Petugas }\end{array}$ & \multicolumn{4}{c}{ Imunisasi Lanjutan } & \multicolumn{2}{c}{ Jumlah } & \multicolumn{1}{c}{ P } & OR \\
& Kesehatan & f & \% & f & \% & n & \% & & \\
\hline 1 & Mendukung & 24 & 48.0 & 26 & 52.0 & 24 & 100.0 & 0.045 & 5.804 \\
2 & Tidak & 1 & 14.3 & 6 & 85.7 & 7 & 100.0 & & \\
& Mendukung & & & & & & & & \\
\hline
\end{tabular}

Berdasarkan tabel 5, dapat dilihat bahwa dari 7 responden yang tidak mendapatkan dukungan dari petugas kesehatan sebanyak 6 orang (85.7\%) tidak memberikan imunisasi lanjutan pada balita, sedangkan dari 24 responden yang mendapatkan dukungan dari petugas kesehatan untuk memberikan imunisasi lanjutan sebanyak 26 orang (52.0\%) namun tidak memberikan imunisasi lanjutan secara lengkap pada balita.

Hasil uji statistik diperoleh $p$-value $=0.045$, artinya ada hubungan antara dukungan petugas kesehatan dengan kelengkapan imunisasi lanjutan pada balita di wilayah kerja Puskesmas Leupung Kabupaten Aceh Besar, dan nilai OR = 5.804, yang berarti ibu yang tidak mendapatkan dukungan dari peran petugas kesehatan mempunyai peluang 5 kali lebih besar untuk tidak memberikan imunisasi lanjutan pada balita.

\section{PEMBAHASAN}


Journal of Healthcare Technology and Medicine Vol. 6 No. 2 Oktober 2020

Universitas Ubudiyah Indonesia

e-ISSN : 2615-109X

\section{Karakteristik Responden}

Berdasarkan hasil penelitian dapat dilihat bahwa dari 57 responden, balita yang tidak mendapatkan imunisasi lanjutan lengkap sebanyak 33 orang (59.9\%), sedangkan balita yang mendapatkan imunisasi lanjutan lengkap sebanyak 24 orang $(42.1 \%)$. Ibu berumur dalam rentang 30-39 tahun sebanyak 30 orang (52.6\%), ibu berumur dalam rentang 20-29 tahun sebanyak 18 orang (31.6\%), dan ibu yang berumur dalam rentang 40-49 tahun sebanyak 9 orang $(15.8 \%)$. Balita yang berjenis kelamin perempuan sebanyak 33 orang $(59.9 \%)$, sedangkan balita yang berjenis kelamin laki-laki sebanyak 24 orang (42.1\%). Ibu yang berpendidikan rendah $(\leq$ SLTA) sebanyak 48 orang $(84.2 \%)$, sedangkan yang ibu yang berpendidikan tinggi ( $\geq$ diploma) sebanyak 9 orang $(15.8 \%$ ). Ibu yang tidak bekerja sebanyak 49 orang (86.0\%), dan ibu yang bekerja sebanyak 8 orang $(14.0 \%)$.

\section{Pengetahuan}

Berdasarkan hasil penelitian dapat dilihat bahwa ibu yang berpengetahuan rendah tentang pemberian imunisasi lanjutan pada balita sebanyak 24 orang (92.3\%) tidak memberikan imunisasi lanjutan secara lengkap pada balitanya, namun masih ada pula ibu yang berpengetahuan tinggi tentang pemberian imunisasi lanjutan pada balita tidak memberikan imunisasi lanjutan lengkap pada balitanya sebanyak 9 orang (29.0\%). Hasil uji statistik menggunakan aplikasi komputer diperoleh p-value $=0.0001$, dengan artian Ho ditolak, artinya ada hubungan pengetahuan ibu tentang imunisasi lanjutan dengan kelengkapan imunisasi lanjutan pada balita di wilayah kerja Puskesmas Leupung Kabupaten Aceh Besar. Pada hasil statistik juga diperoleh nilai $\mathrm{OR}=29.333$, yang berarti ibu yang berpengetahuan rendah tentang imunisasi lanjutan pada balita memiliki peluang 29 kali lebih besar untuk tidak memberikan imunisasi lanjutan secara lengkap kepada balitanya dibandingkan dengan ibu dengan pengetahuan tinggi terhadap pemberian imunisasi lanjutan.

Hasil penelitian ini sejalan dengan penelitian yang telah dilakukan oleh Munawaroh, Syamsulhuda dan Widjanarko tentang beberapa faktor yang berhubungan dengan praktik imunisasai pentavalent booster lanjutan di Wilayah Kerja Puskesmas Mangunsari Salatiga pada tahun 2016, didapatkan hasil bahwa praktek imunisasi pentavalent booster yang belum terlaksana lebih banyak dijumpai pada kelompok responden dengan pengetahuan tentang imunisasi pentavalent yang kurang (40\%), dengan $p$-value $=0,039$, artinya ada hubungan yang signifikan antara pengetahuan dengan praktik imunisasi pentavalent booster ${ }^{8}$. 
Journal of Healthcare Technology and Medicine Vol. 6 No. 2 Oktober 2020

Universitas Ubudiyah Indonesia

e-ISSN : 2615-109X

Sama halnya dengan hasil penelitian yang dilakukan oleh Pangaribuan tentang determinan kelengkapan imunisasi lanjutan pada batita di wilayah kerja Puskesmas Sentosa Baru Kota Medan tahun 2018, dapat disimpulkan bahwa terdapat hubungan yang signifikan antara pengetahuan ibu dengan kelengkapan imunisasi lanjutan pada batita dengan nilai $\mathrm{p}=0,001$, dan tingkat pengetahuan mempunyai nilai $\operatorname{Exp}(\mathrm{B})$ sebesar 6,789 artinya responden yang mempunyai pengetahuan yang baik 6,7 kali lebih besar akan melengkapi imunisasi lanjutan pada batita daripada ibu yang memiliki tingkat pengetahuan kurang baik ${ }^{9}$.

Hasil penelitian yang telah dilakukan oleh Harahap, Perwitasari dan Puspasari tentang gambaran pengetahuan dan motivasi ibu tentang pemberian imunisasi DPT lanjutan (booster) di Puskesmas Simpang IV Sipin Kota Jambi, dapat disimpulkan bahwa sebagian besar responden memiliki pengetahuan kurang sebanyak $44.3 \%$ dan sebagian besar balita tidak mendapatkan imunisasi DPT Lanjutan (booster) sebanyak 83,2\% ${ }^{10}$.

Hasil penelitian tersebut juga sesuai dengan teori yang dikemukakan dalam buku Smiley (1947), pengetahuan dapat didefenisikan sebagai fakta atau informasi yang kita anggap benar berdasarkan pemikiran yang melibatkan pengujian empiris (pemikiran tentang fenomena yang diobservasi secara langsung) atau berdasarkan proses berpikir lainnya seperti pemberian alasan logis atau penyelesaian masalah. Pada dasarnya pengetahuan adalah kesadaran dan pemahaman kita terhadap sesuatu dan penerimaan kita sebagai kelompok bahwa pemahaman ini benar ${ }^{11}$.

Hasil pengumpulan data selama penelitian, peneliti melihat bahwa masih banyak ibu-ibu yang tidak mau membawa anaknya untuk diberikan imunisasi lanjutan dengan alasan anak sudah mendapatkan imunisasi dasar lengkap dan anak telah terlindungi dari berbagai penyakit dan mereka tidak mengetahui manfaat dari pada imunisasi lanjutan ini yang dapat meningkatkan kekebalan anak terhadap virus yang dapat dicegah dengan imunisasi, ibu tidak mengetahui penyakit apa yang dapat terhindar apabila anak diberikan imunisasi dan pada usia berapa bulan anak diberikan imunisasi lanjutan. Selain itu pula ibuibu yang sudah mengetahui pentingnya memberikan imunisasi lanjutan/booster kepada balitanya namun tetap tidak membawa anaknya untuk diberikan imunisasi dengan alasan ada yang bekerja, dan ada pula yang tidak berani membawa anak ke petugas kesehatan dikarenakan sedang pandemi covid-19, sehingga terlewatlah jadwal pemberian imunisasi lanjutan pada balitanya.

Dengan demikian peneliti menyimpulkan bahwa pengetahuan yang baik menjadi acuan seseorang untuk dapat merubah sikap dan tindakannya dari arah negative kearah positif. Jadi 
Journal of Healthcare Technology and Medicine Vol. 6 No. 2 Oktober 2020

Universitas Ubudiyah Indonesia

e-ISSN : 2615-109X

apabila semakin rendah pengetahuan ibu tentang imunisasi lanjutan pada balita, maka hal ini akan menjadi faktor pendorong untuk ibu tidak membawa balitanya untuk diberikan imunisasi lanjutan, begitu pula sebaliknya semakin tinggi pengetahuan ibu tentang imunisasi lanjutan, maka ibu akan membawa anaknya untuk mendapatkan imunisasi lanjutan secara lengkap.

\section{Sikap}

Berdasarkan hasil penelitian dapat dilihat bahwa ibu yang bersikap negatif terhadap pemberian imunisasi lanjutan pada balita sebanyak 21 orang $(95.5 \%)$ tidak memberikan imunisasi lanjutan secara lengkap pada balitanya, sedangkan ibu yang bersikap positif terhadap pemberian imunisasi lanjutan sebanyak 12 orang $(34.3 \%)$ juga tidak lengkap mendapatkan imunisasi lanjutan pada balita. Hasil uji statistik diperoleh $p$-value $=0.0001$, Ho ditolak, artinya ada hubungan yang signifikan antara sikap dengan kelengkapan imunisasi lanjutan pada balita di wilayah kerja Puskesmas Leupung Kabupaten Aceh Besar. Hasil uji juga diperoleh nilai $\mathrm{OR}=40.250$, yang berarti ibu yang memiliki sikap negative terhadap imunisasi lanjutan memiliki peluang 40 kali lebih besar untuk tidak memberikan imunisasi lanjutan secara lengkap pada balitanya dibandingkan dengan ibu yang memiliki sikap positif terhadap pemberian imunisasi lanjutan.

Hasil penelitian ini sejalan dengan penelitian yang dilakukan oleh Afrilia dan Fitriani di Puskesmas Curug Tahun 2017, didapatkan hasil bahwa terdapat hubungan yang signifikan antara sikap ibu dengan kelengkapan imunisasi balita dengan nilai $\mathrm{p}=0,001$ dan $\mathrm{OR}=28.800$, yang artinya ibu yang memiliki sikap positif berpeluang 29 kali lebih besar memiliki status imunisasi lanjutan lengkap dibandingkan dengan ibu yang memiliki sikap negative ${ }^{4}$. Sama halnya dengan hasil penelitian yang dilakukan oleh Pangaribuan tentang determinan kelengkapan imunisasi lanjutan pada batita di wilayah kerja Puskesmas Sentosa Baru Kota Medan tahun 2018, dapat disimpulkan bahwa terdapat hubungan sikap dengan kelengkapan imunisasi lanjutan pada batita dengan nilai $\mathrm{p}=0,033^{9}$.

Sikap adalah respon tertutup seseorang terhadap stimulus atau objek tertentu, yang sudah melibatkan faktor pendapat dan emosi yang bersangkutan. Sikap melibatkan pikiran, perasaan, perhatian, dan gejala kejiwaan yang lain ${ }^{12}$. 
Journal of Healthcare Technology and Medicine Vol. 6 No. 2 Oktober 2020

Universitas Ubudiyah Indonesia

e-ISSN : 2615-109X

Hasil pengumpulan data selama penelitian, peneliti melihat bahwa masih banyak ibuibu yang tidak mau membawa balitanya untuk diberikan imunisasi lanjutan dengan sikap bahwa imunisasi lanjutan tidak terlalu penting karena anak telah diberikan imunisasi dasar dan ibu beranggapan bahwa setelah anak diberikan imunisasi dasar, anak juga masih mudah terserang penyakit, serta alasan lainnya karena ibu tidak tega melihat anak mengalami demam, kakinya sakit setelah diberikan imunisasi sehingga ibu tidak membawakan anaknya untuk imunisasi selanjutnya.

Dengan demikian peneliti menyimpulkan bahwa sikap seseorang menjadi hal penting dalam mengambil suatu tindakan, dalam hal ini adalah tindakan untuk membawa anaknya agar mendapatkan imunisasi lanjutan. Merubah sikap seseorang itu tidaklah mudah, dibutuhkan kesabaran dan ketekunan untuk terus berupaya agar pandangan yang salah terhadap imunisasi lanjutan pada balita bisa teratasi sehingga semakin banyak balita yang mendapatkan imunisasi lanjutan secara lengkap. Oleh karena itu peran dari petugas kesehatan baik itu bidan, petugas puskesmas dan dinas kesehatan sangat dibutuhkan dan sangat penting dalam memberikan edukasi dan pendidikan kesehatan secara terus menerus untuk merubah pandangan setiap ibu khususnya tentang imunisasi lanjutan/booster (DPT HB-Hib dan campak).

\section{Dukungan Suami}

Berdasarkan hasil penelitian dapat dilihat bahwa dari 33 responden, yang tidak mendapatkan dukungan dari suami sebanyak 30 orang (90.9\%) tidak memberikan imunisasi lanjutan lengkap pada balita, sedangkan dari 24 responden, yang mendapatkan dukungan dari suami sebanyak 3 orang (12.5\%) tidak memberikan imunisasi lanjutan lengkap pada balita. Hasil uji statistik diperoleh $p$ value $=0.0001$, artinya ada hubungan yang bermakna antara dukungan suami dengan kelengkapan imunisasi lanjutan pada balita di wilayah kerja Puskesmas Leupung Kabupaten Aceh Besar, dan nilai OR =70.000, yang berarti ibu yang tidak mendapatkan dukungan dari suami mempunyai peluang 70 kali lebih besar untuk tidak mendapatkan imunisasi lanjutan pada balitanya dibandingkan dengan ibu yang mendapatkan dukungan dari suami.

Hasil penelitian ini sejalan dengan penelitian yang dilakukan oleh Munawaroh, Syamsulhuda dan Widjanarko tentang beberapa faktor yang berhubungan dengan praktik imunisasai pentavalent booster lanjutan di Wilayah Kerja Puskesmas Mangunsari Salatiga pada tahun 2016, didapatkan hasil bahwa sebagian besar responden kurang mendapatkan 
Journal of Healthcare Technology and Medicine Vol. 6 No. 2 Oktober 2020

Universitas Ubudiyah Indonesia

e-ISSN : 2615-109X

dukungan dari suami/keluarga dalam praktik imunisasi pentavalent booster dengan nilai $\mathrm{p}$ $=0,001$, artinya ada hubungan yang signifikan antara dukungan suami/keluarga dengan praktik imunisasi pentavalent booster ${ }^{8}$.

Hasil pengumpulan data selama penelitian, peneliti melihat bahwa masih banyak ibuibu yang tidak mau membawa balitanya untuk diberikan imunisasi lanjutan dengan alasan tidak mendapatkan persetujuan dari suami dan keluarga untuk membawa anak diberikan imunisasi dikarenakan banyak informasi tentang vaksin imunisasi yang terbuat dari barang haram, serta karena efek samping dari imunisasi itu sendiri yang membuat ibu dan keluarga tidak ingin membawa anaknya untuk diberikan imunisasi lanjutan.

Dengan demikian peneliti menyimpulkan bahwa dukungan suami menjadi hal yang tidak kalah pentingnya dari pada pengetahuan ibu tentang imunisasi lanjutan pada balita, karena suami menjadi penentu dalam pengambilan keputusan didalam keluarga, jika suami tidak memberikan izin untuk memberikan imunisasi pada anaknya, maka ibu-ibu tidak dapat membawa anaknya untuk diberikan imunisasi lanjutan. Disini perlunya peran dari petugas kesehatan untuk memberikan pemahaman kepada suami tentang imunisasi lanjutan pada balita, agar suami memahami pentingnya pemberian imunisasi lanjutan pada balitanya.

\section{Dukungan Petugas Kesehatan}

Berdasarkan hasil penelitian dapat dilihat bahwa dari 7 responden yang tidak mendapatkan dukungan dari petugas kesehatan sebanyak 6 orang (85.7\%) tidak memberikan imunisasi lanjutan pada balita, sedangkan dari 24 responden yang mendapatkan dukungan dari petugas kesehatan untuk memberikan imunisasi lanjutan sebanyak 26 orang $(52.0 \%)$ namun tidak memberikan imunisasi lanjutan secara lengkap pada balita. Hasil uji statistik diperoleh $p$-value $=0.045$, artinya ada hubungan antara dukungan petugas kesehatan dengan kelengkapan imunisasi lanjutan pada balita di wilayah kerja Puskesmas Leupung Kabupaten Aceh Besar, dan nilai OR = 5.804, yang berarti ibu yang tidak mendapatkan dukungan dari peran petugas kesehatan mempunyai peluang 5 kali lebih besar untuk tidak memberikan imunisasi lanjutan pada balita.

Hasil penelitian ini sejalan dengan penelitian yang dilakukan oleh Munawaroh, Syamsulhuda dan Widjanarko tentang beberapa faktor yang berhubungan dengan praktik imunisasai pentavalent booster lanjutan di Wilayah Kerja Puskesmas Mangunsari Salatiga pada tahun 2016, didapatkan hasil bahwa sebagian besar responden sudah mendapatkan dukungan dari tenaga kesehatan dalam praktik imunisasi pentavalent booster, dengan nilai 
Journal of Healthcare Technology and Medicine Vol. 6 No. 2 Oktober 2020

Universitas Ubudiyah Indonesia

e-ISSN : 2615-109X

$p=0,0001$, artinya ada hubungan yang signifikan antara dukungan tenaga kesehatan dengan praktik imunisasi pentavalent booster ${ }^{8}$.

Sama halnya dengan hasil penelitian yang dilakukan oleh Pangaribuan tentang determinan kelengkapan imunisasi lanjutan pada batita di wilayah kerja Puskesmas Sentosa Baru Kota Medan tahun 2018, dapat disimpulkan bahwa terdapat hubungan yang signifikan antara dukungan petugas kesehatan dengan kelengkapan imunisasi lanjutan pada batita dengan nilai $\mathrm{p}=0,0001^{9}$.

Hasil pengumpulan data selama penelitian, peneliti melihat bahwa sudah sebanyak $87.7 \%$ petugas kesehatan yang mendukung ibu untuk memberikan imunisasi lanjutan pada balitanya, namun sebagian besar ibu masih tidak peduli dengan apa yang disampaikan oleh petugas kesehatan, hal ini dipengaruhi oleh tingkat pendidikan, pengetahuan, sikap dan dukungan suami. Namun demikian, petugas kesehatan tetap harus secara terus menerus memberian edukasi kepada ibu dan keluarganya tentang pentingnya pemberian imunisasi lanjutan balitanya, hal ini bertujuan untuk mengurangi angka kesakitan, kecatatan bahkan kematian yang disebabkan oleh penyakit yang dapat dicegah dengan imunisasi.

\section{SIMPULAN}

Berdasarkan hasil penelitian dapat disimpulkan bahwa ada hubungan pengetahuan ( $p$ value $=0.0001, \mathrm{OR}=29.333$ ), sikap ( $p$ value $=0.0001, \mathrm{OR}=40.250)$, dukungan suami ( $p$ value $=0.0001, \mathrm{OR}=70.000)$, dukungan petugas kesehatan $(p$ value $=0.045, \mathrm{OR}=5.804)$ dengan kelengkapan imunisasi lanjutan pada balita di wilayah kerja Puskesmas Leupung Kabupaten Aceh Besar.

\section{SARAN}

Diharapkan kepada petugas kesehatan agar dapat memberikan edukasi secara berkesinambungan kepada masyarakat khususnya tentang imunisasi pada bayi dan balita melalui penyuluhan kesehatan, penyebaran brosur, pemasangan baliho ditempat-tempat strategis serta penyebaran video melalui akun media sosial yang berisikan tentang pentingnya pemberian imunisasi pada anak, serta menghilangkan kesalahpahaman informasi (berita hoax) yang banyak beredar di masyarakat, petugas kesehatan dapat pula bekerja sama dengan kader, tokoh masyarakat, tokoh agama, dan instansi pendidikan kesehatan agar bersama-sama dapat menggalakkan slogan "imunisasi itu penting" bagi anak sebagai generasi penerus bangsa. Dengan meningkatnya cakupan imunisasi lanjutan pada balita maka dapat menurunkan angka 
Journal of Healthcare Technology and Medicine Vol. 6 No. 2 Oktober 2020

Universitas Ubudiyah Indonesia

e-ISSN : 2615-109X

kesakitan, kecatatan bahkan kematian yang disebabkan oleh penyakit yang sebenarnya dapat dicegah dengan imunisasi.

\section{UCAPAN TERIMA KASIH}

Ucapan terima kasih kepada Universitas Ubudiyah Indonesia yang telah memberikan dukungan finansial dalam penelitian ini dan ucapan terima kasih kepada Kepala Puskesmas Leupung Kabupaten Aceh Besar yang telah memberikan izin penelitian diwilayah kerjanya dan para responden yang telah membantu peneliti dalam memberikan informasi yang dibutuhkan peneliti.

\section{DAFTAR PUSTAKA}

1. Permenkes RI 2017. Peraturan Menteri Kesehatan, Nomor 12 Tentang Penyelenggaraan Imunisasi. Вестник Росздравнадзора. 2017;6:5-9.

2. Rahma S dan F. Analisis Pelaksanaan Program Imunisasi Dpt- Hb- Hib Pentavalen Booster Pada Baduta Di Puskesmas Kota Semarang (Studi Kasus Pada Puskesmas Halmahera). J Kesehat Masy. 2019;7(1):48-56.

3. Kemenkes RI. Profil Kesehatan Indonesia 2018 [Indonesia Health Profile 2018].; 2019. http://www.depkes.go.id/resources/download/pusdatin/profil-kesehatanindonesia/Data-dan-Informasi_Profil-Kesehatan-Indonesia-2018.pdf.

4. Afrilia EM, Fitriani A. Kelengkapan Imunisasi Lanjutan Pada Batita Di Puskesmas Curug Tahun 2017. 2017.

5. WHO UNICEF. Global and regional immunization profile. Who. 2019.

6. KEMENKES RI. Profil Kesehatan Indonesia Tahun 2019. Vol 42.; 2020.

7. Aceh DK. Posyandu Aceh. Dk. 2019;53(9):1689-1699.

8. Syamsulhuda BM SB, Munawaroh A, Widjanarko B. Beberapa Faktor Yang Berhubungan Dengan Praktik Imunisasi Pentavalen Booster Di Wilayah Kerja Puskesmas Mangunsari Salatiga. J Kesehat Masy. 2016;4(3):949-959.

9. Pangaribuan. Determinan Kelengkapan Imunisasi Lanjutan Pada Batita Di Wilayah Kerja Puskesmas Sentosa Baru Kota Medan Tahun 2018.; 2018.

10. Harahap RR, Perwitasari T, Puspasari A. Gambaran Pengetahuan dan Motivasi Ibu tentang Pemberian Imunisasi DPT Lanjutan (Booster) di Puskesmas Simpang IV Sipin Kota Jambi. J Akad Baiturrahim Jambi. 2019;8(2):61-65. doi:10.36565/jabj.v8i2.14

11. Smiley $\mathrm{CH}$. Atmospheric refraction at low altitudes. Astron J. 1947. doi:10.1086/105979

12. Notoatmodjo S. Promosi Kesehatan Dan Perilaku Kesehatan. Jakarta: PT Rineka Cipta; 2012. 